\title{
Immunohistochemical features of the portal tract mononuclear cell infiltrate in chronic aggressive hepatitis
}

\author{
Giorgio Senaldi, Bernard Portmann, Alex P Mowat, Giorgina Mieli-Vergani, Diego Vergani
}

\begin{abstract}
The portal tract mononuclear cell infiltrate has been characterised in 28 liver biopsy samples showing features of chronic aggressive hepatitis from 12 patients with autoimmune chronic active hepatitis, 12 with primary sclerosing cholangitis, and four with other chronic liver diseases (two with $\alpha_{1}$-antitrypsin deficiency, one with Wilson's disease, and one with chronic hepatitis B infection). In all patients liver disease had started in childhood. The mononuclear cell infiltrate was investigated by a two step immunoperoxidase technique using monoclonal antibodies to: total, $\alpha / \beta$ $T$ cell receptor positive, helper/inducer, suppressor/cytotoxic $T$ lymphocytes; B lymphocytes; killer/natural killer cells; monocyte/ macrophages; and to the activation markers HLA-DR antigens, interleukin 2 receptor (IL-2R), transferrin receptor, and 4 F2Ag. In all samples the infiltrate consisted of mainly $\alpha / \beta T$ cell receptor $T$ lymphocytes. Although $\mathbf{T}$ helper/inducer cells predominated in patients with autoimmune chronic active hepatitis, $T$ suppressor/cytotoxic lymphocytes were preponderant in patients with primary sclerosing cholangitis and the other chronic liver diseases. Killer/natural killer cells accounted for up to $25 \%$ of the mononuclear cell infiltrate in patients with autoimmune chronic active hepatitis, being rare or absent in the other diseases. Monocytes/macrophages were always found, but they were more numerous in primary sclerosing cholangitis than in the other chronic liver diseases. B lymphocytes were rare or absent in all subjects. Activated mononuclear cells were present in all subjects, but although in patients with autoimmune chronic active hepatitis and primary sclerosing cholangitis most cells of the infiltrate expressed HLA-DR antigens and up to $75 \% \mathrm{IL}-\mathbf{2 R}$, in other forms of chronic liver diseases HLA-DR positive cells were less common and IL-2R positive cells were rare or absent. These results show that the cells responsible for the histological characteristics of chronic aggressive hepatitis vary in their functional phenotype and state of activation according to the type of underlying liver disorder, confirming the involvement of different pathogenetic mechanisms.
\end{abstract}

(Arch Dis Child 1992;67:1447-53)

Mononuclear cell infiltrate and piecemeal necrosis are the histological hallmarks of chronic aggressive hepatitis. ${ }^{2}$ They are observed in a number of chronic liver diseases of various aetiologies. It is believed that among the infiltrating mononuclear cells are the effectors of piecemeal necrosis and the stimulators of fibrogenesis, which ultimately result in loss of hepatic parenchyma and cirrhosis. ${ }^{3}$

Since monoclonal antibodies have been available for immunohistochemical use, several studies characterising the mononuclear cell infiltrate have been performed in adult patients with different forms of chronic aggressive hepatitis, including autoimmune chronic active hepatitis, ${ }^{4-6}$ hepatitis $B$ virus related chronic active hepatitis, ${ }^{40}$ primary biliary cirrhosis, ${ }^{4} 681112$ primary sclerosing cholangitis, ${ }^{11-13}$ chronic alcoholic hepatitis, ${ }^{6} 14$ and non-A-non$B$ chronic active hepatitis. ${ }^{10}$ In childhood, the histological picture of chronic aggressive hepatitis, characteristic of chronic active hepatitis, is also often found in patients with primary sclerosing cholangitis, ${ }^{15}$ hepatitis $\mathrm{B}$ virus related chronic liver disease, ${ }^{16}$ Wilson's disease, ${ }^{17}$ and occasionally $\alpha_{1}$-antitrypsin deficiency. ${ }^{18}$ To date no study characterising the mononuclear cell infiltrate in children with chronic liver diseases has been reported. Moreover, although circulating activated $\mathrm{T}$ lymphocytes in various forms of chronic aggressive hepatitis have been considered to be of pathogenic and clinical importance, ${ }^{19-21}$ in only three studies has the expression of activation markers on the hepatic mononuclear cell infiltrate been investigated. ${ }^{8} 1013$

We have characterised the portal tract mononuclear cell infiltrate in liver biopsy samples from children with chronic liver diseases and features of chronic aggressive hepatitis using a panel of monoclonal antibodies directed against markers of function and activation.

\section{Patients, materials, and methods}

PATIENTS

Twenty eight subjects (18 female patients; median age 12 years, range 1-20 years) with chronic liver disease starting in childhood and a histological picture of chronic aggressive hepatitis at presentation were studied (tables 1-3). Three of these subjects, all with chronic active hepatitis, were older than 16 years of age (17, 18 , and 20 years) at the time of study but were 10,11 , and 13 years old at presentation. Liver disease was considered to be active when the total histopathological score was greater than 3 (see later) or values of aspartate transaminase were more than twice the upper normal value (45 IU/1), or both.

Twelve patients had autoimmune chronic active hepatitis diagnosed according to internationally agreed criteria ${ }^{22}$ (table 1). Three were 
tested before treatment was started and had high values of asparatate transaminase, IgG, non-organ specific autoantibodies, and the presence of piecemeal necrosis in the liver biopsy sample. Seven were tested while receiving immunosuppressive treatment (azathioprine $1-1.5 \mathrm{mg} / \mathrm{kg} /$ day and prednisolone $0.5-2 \mathrm{mg} / \mathrm{kg} /$ day in six patients; prednisolone $0.5 \mathrm{mg} / \mathrm{kg} /$ day in one patient); three had signs of active disease with increased levels of aspartate transaminase, IgG, autoantibodies, and piecemeal necrosis at histology. The remaining four treated patients and two further patients tested during remission in the absence of treatment, had no biochemical, immunological, nor histological evidence of active disease. Three of the 12 children had associated cirrhosis.

Twelve children had primary sclerosing cholangitis (table 2). All had characteristic endoscopic retrograde cholangiopancreatographic changes and 10 had associated inflammatory bowel disease. Three were tested at diagnosis before treatment and nine while receiving treatment (prednisolone $0.5-1 \mathrm{mg} / \mathrm{kg} / \mathrm{day}$ in five patients; azathioprine $1-1.5 \mathrm{mg} / \mathrm{kg} /$ day and prednisolone $0.5 \mathrm{mg} / \mathrm{kg} /$ day in two patients; penicillamine $20 \mathrm{mg} / \mathrm{kg} / \mathrm{day}$ in one patient; sulphasalazine (Salazopyrin, Kabi Pharmacia),

Table 1 Clinical, biochemical, immunological, and histological details of the patients with autoimmune chronic active hepatitis at the time of testing

\begin{tabular}{|c|c|c|c|c|c|c|c|c|c|c|c|c|}
\hline \multirow{2}{*}{$\begin{array}{l}\text { Patient } \\
\text { No }\end{array}$} & \multirow[t]{2}{*}{ Sex } & \multirow{2}{*}{$\begin{array}{l}\text { Age } \\
\text { (years) }\end{array}$} & \multirow{2}{*}{$\begin{array}{l}\text { Disease } \\
\text { status }\end{array}$} & \multirow{2}{*}{$\begin{array}{l}\text { Immuno- } \\
\text { suppressive } \\
\text { treatment }\end{array}$} & \multirow[t]{2}{*}{ Cirrhosis } & \multirow{2}{*}{$\begin{array}{l}\text { Portal } \\
\text { tract } \\
\text { infiltratef }\end{array}$} & \multirow{2}{*}{$\begin{array}{l}\text { Piecemeal } \\
\text { necrosist }\end{array}$} & \multirow{2}{*}{$\begin{array}{l}\text { Aspartate } \\
\text { transuminase } \\
(I U / l) \neq\end{array}$} & \multirow{2}{*}{$\underset{(g / l) \mathscr{I}}{\operatorname{Ig} G}$} & \multicolumn{3}{|c|}{ Autoantibodies? } \\
\hline & & & & & & & & & & $A N A$ & $A S M A$ & $L K M I$ \\
\hline $\begin{array}{r}1 \\
2 \\
3 \\
4 \\
5 \\
6 \\
7 \\
8 \\
9 \\
10 \\
11 \\
12\end{array}$ & $\begin{array}{l}\mathbf{F} \\
\mathbf{F} \\
\mathbf{M} \\
\mathbf{M} \\
\mathbf{M} \\
\mathbf{F} \\
\mathbf{F} \\
\mathbf{F} \\
\mathbf{F} \\
\mathbf{F} \\
\mathbf{F} \\
\mathbf{F}\end{array}$ & $\begin{array}{r}13 \\
15 \\
20 \\
13 \\
17 \\
15 \\
18 \\
2 \\
12 \\
15 \\
6 \\
5\end{array}$ & $\begin{array}{l}\text { Active } \\
\text { Inactive } \\
\text { Inactive } \\
\text { Inactive } \\
\text { Inactive } \\
\text { Inactive } \\
\text { Active } \\
\text { Active } \\
\text { Active } \\
\text { Inactive } \\
\text { Active } \\
\text { Active }\end{array}$ & $\begin{array}{l}\text { Pred/aza } \\
\text { None } \\
\text { Pred/aza } \\
\text { Pred/aza } \\
\text { Pred/aza } \\
\text { None } \\
\text { Pred/aza } \\
\text { Pred } \\
\text { None } \\
\text { Pred/aza } \\
\text { None } \\
\text { None }\end{array}$ & $\begin{array}{l}\text { Present } \\
\text { Present } \\
\text { Absent } \\
\text { Absent } \\
\text { Absent } \\
\text { Absent } \\
\text { Absent } \\
\text { Present } \\
\text { Absent } \\
\text { Absent } \\
\text { Absent } \\
\text { Absent }\end{array}$ & $\begin{array}{l}2 \\
2 \\
2 \\
2 \\
2 \\
2 \\
3 \\
3 \\
4 \\
2 \\
3 \\
2\end{array}$ & $\begin{array}{l}4 \\
1 \\
2 \\
2\end{array}$ & $\begin{array}{r}120 \\
26 \\
53 \\
26 \\
24 \\
30 \\
371 \\
157 \\
172 \\
33 \\
1260 \\
185\end{array}$ & $\begin{array}{l}23 \cdot 7 \\
7 \cdot 3 \\
\text { ND } \\
11 \cdot 5 \\
13 \cdot 3 \\
14 \cdot 2 \\
19 \cdot 5 \\
20 \cdot 8 \\
50 \cdot 3 \\
11 \cdot 7 \\
19 \cdot 2 \\
21 \cdot 8\end{array}$ & $\begin{array}{l}\text { Negative } \\
\text { Positive } \\
\text { ND } \\
\text { Negative } \\
\text { Negative } \\
\text { Negative } \\
\text { Positive } \\
\text { Positive } \\
\text { Positive } \\
\text { Negative } \\
\text { Positive } \\
\text { Negative }\end{array}$ & $\begin{array}{l}\text { Negative } \\
\text { Negative } \\
\text { ND } \\
\text { Negative } \\
\text { Negative } \\
\text { Positive } \\
\text { Negative } \\
\text { Positive } \\
\text { Negative } \\
\text { Negative } \\
\text { Negative } \\
\text { Negative }\end{array}$ & $\begin{array}{l}\text { Positive } \\
\text { Negative } \\
\text { ND } \\
\text { Negative } \\
\text { Positive } \\
\text { Negative } \\
\text { Negative } \\
\text { Negative } \\
\text { Negative } \\
\text { Negative } \\
\text { Negative } \\
\text { Positive }\end{array}$ \\
\hline
\end{tabular}

Pred=prednisolone; aza =azathioprine

†Liver biopsy samples were assessed semiquantitatively, as desribed in text.

$\$$ Normal values $<45 \mathrm{IU} / \mathrm{l}$

Normal values for children aged between 2 and 5 years $>5-<17 \mathrm{~g} / 1 ; 5$ and 16 years $>7-<18 \mathrm{~g} / \mathrm{l}$.

ITitres $\geqslant 1: 40$. ANA = antinuclear antibodies; ASMA = smooth muscle antibody; LKMl =liver kidney microsomal antibody type 1 . $\mathrm{ND}=$ not determined.

Table 2 Clinical, biochemical, immunological, and histological details of the patients with sclerosing cholangitis at the time of testing

\begin{tabular}{|c|c|c|c|c|c|c|c|c|c|c|c|c|}
\hline \multirow{2}{*}{$\begin{array}{l}\text { Patient } \\
\text { No }\end{array}$} & \multirow[t]{2}{*}{ Sex } & \multirow{2}{*}{$\begin{array}{l}\text { Age } \\
\text { (years) }\end{array}$} & \multirow{2}{*}{$\begin{array}{l}\text { Disease } \\
\text { status }\end{array}$} & \multirow{2}{*}{$\begin{array}{l}\text { Immuno- } \\
\text { suppressive } \\
\text { treatment }\end{array}$} & \multirow[t]{2}{*}{ Cirrhosis } & \multirow{2}{*}{$\begin{array}{l}\text { Portal } \\
\text { tract } \\
\text { infiltratet }\end{array}$} & \multirow{2}{*}{$\begin{array}{l}\text { Piecemeal } \\
\text { necrosist }\end{array}$} & \multirow{2}{*}{$\begin{array}{l}\text { Aspartate } \\
\text { transaminase } \\
(I U / l) \neq\end{array}$} & \multirow{2}{*}{$\underset{(g / l) !}{\operatorname{Ig} G}$} & \multicolumn{3}{|c|}{ Autoantibodies } \\
\hline & & & & & & & & & & $A N A$ & $A S M A$ & $L K M I$ \\
\hline $\begin{array}{r}1 \\
2 \\
3 \\
4 \\
5 \\
6 \\
7 \\
8 \\
9 \\
10 \\
11 \\
12\end{array}$ & $\begin{array}{l}\mathrm{F} \\
\mathbf{M} \\
\mathbf{M} \\
\mathbf{M} \\
\mathbf{M} \\
\mathrm{F} \\
\mathbf{F} \\
\mathrm{F} \\
\mathbf{M} \\
\mathrm{F} \\
\mathrm{F} \\
\mathbf{F}\end{array}$ & $\begin{array}{r}10 \\
8 \\
7 \\
15 \\
12 \\
6 \\
8 \\
12 \\
5 \\
16 \\
12 \\
12\end{array}$ & $\begin{array}{l}\text { Active } \\
\text { Active } \\
\text { Inactive } \\
\text { Inactive } \\
\text { Active } \\
\text { Active } \\
\text { Inactive } \\
\text { Active } \\
\text { Active } \\
\text { Active } \\
\text { Active } \\
\text { Active }\end{array}$ & $\begin{array}{l}\text { Pred } \\
\text { Pred/aza } \\
\text { Pred/aza } \\
\text { Pred } \\
\text { Penicillamine } \\
\text { Pred } \\
\text { Pred } \\
\text { Pred } \\
\text { None\| } \\
\text { None } \\
\text { None } \\
\text { None }\end{array}$ & $\begin{array}{l}\text { Absent } \\
\text { Absent } \\
\text { Present } \\
\text { Absent } \\
\text { Present } \\
\text { Absent } \\
\text { Absent } \\
\text { Absent } \\
\text { Absent } \\
\text { Present } \\
\text { Present } \\
\text { Present }\end{array}$ & $\begin{array}{l}2 \\
2 \\
2 \\
2 \\
2 \\
3 \\
2 \\
2 \\
2 \\
4 \\
2 \\
2\end{array}$ & $\begin{array}{l}1 \\
1 \\
1 \\
1 \\
2 \\
1 \\
1 \\
1 \\
1 \\
3 \\
2 \\
3\end{array}$ & $\begin{array}{r}543 \\
150 \\
47 \\
28 \\
109 \\
98 \\
34 \\
218 \\
197 \\
352 \\
110 \\
740\end{array}$ & $\begin{array}{r}35 \cdot 1 \\
20 \cdot 4 \\
7 \cdot 4 \\
12 \cdot 5 \\
18 \cdot 8 \\
12 \cdot 2 \\
25 \cdot 0 \\
27 \cdot 3 \\
28 \cdot 5 \\
41 \cdot 1 \\
16 \cdot 4 \\
38 \cdot 1\end{array}$ & $\begin{array}{l}\text { Positive } \\
\text { Positive } \\
\text { Negative } \\
\text { Positive } \\
\text { Negative } \\
\text { Negative } \\
\text { Positive } \\
\text { Positive } \\
\text { Positive } \\
\text { Positive } \\
\text { Negative } \\
\text { Positive }\end{array}$ & $\begin{array}{l}\text { Negative } \\
\text { Negative } \\
\text { Negative } \\
\text { Negative } \\
\text { Positive } \\
\text { Positive } \\
\text { Negative } \\
\text { Positive } \\
\text { Negative } \\
\text { Negative } \\
\text { Negative } \\
\text { Positive }\end{array}$ & $\begin{array}{l}\text { Negative } \\
\text { Negative } \\
\text { Negative } \\
\text { Negative } \\
\text { Negative } \\
\text { Negative } \\
\text { Negative } \\
\text { Negative } \\
\text { Negative } \\
\text { Negative } \\
\text { Negative } \\
\text { Negative }\end{array}$ \\
\hline
\end{tabular}

Pred = prednisolone; aza =azathioprine

† Liver biopsy samples were assessed semiquantitatively, as desribed in text.

$\ddagger$ Normal values $<45$ IU/l.

Normal values for children aged between 2 and 5 years $>5-<17 \mathrm{~g} / \mathrm{l} ; 5$ and 16 years $>7-<18 \mathrm{~g} / \mathrm{l}$.

ITitres $\geqslant 1: 40$. ANA=antinuclear antibody; ASMA=smooth muscle antibody; LKMI=liver kidney microsomal antibody type 1 . Patient discontinued treatment.

$\mathrm{ND}=$ not determined.

Table 3 Clinical, biochemical, immunological, and histological details of the patients with other forms of chronic aggressive hepatitis

\begin{tabular}{|c|c|c|c|c|c|c|c|c|c|c|c|c|}
\hline \multirow{2}{*}{$\begin{array}{l}\text { Patient } \\
\text { No } \\
\text { (diagnosis) }^{*}\end{array}$} & \multirow[t]{2}{*}{ Sex } & \multirow{2}{*}{$\begin{array}{l}\text { Age } \\
\text { (years) }\end{array}$} & \multirow{2}{*}{$\begin{array}{l}\text { Disease } \\
\text { status }\end{array}$} & \multirow{2}{*}{$\begin{array}{l}\text { Immuno- } \\
\text { suppressive } \\
\text { treatment:" }\end{array}$} & \multirow[t]{2}{*}{ Cirrhosis } & \multirow{2}{*}{$\begin{array}{l}\text { Portal } \\
\text { tract } \\
\text { infiltratef }\end{array}$} & \multirow{2}{*}{$\begin{array}{l}\text { Piecemeal } \\
\text { necrosist }\end{array}$} & \multirow{2}{*}{$\begin{array}{l}\text { Aspartate } \\
\text { transaminase } \\
(I U / l) \neq\end{array}$} & \multirow{2}{*}{$\underset{(g / l) !}{\operatorname{Ig}(}$} & \multicolumn{3}{|c|}{ Autoantibodies } \\
\hline & & & & & & & & & & $\overline{A N A}$ & $A S M A$ & $L K M I$ \\
\hline $\begin{array}{l}\text { (AIATD) } \\
\text { (A1ATD) } \\
\text { (WD) } \\
\text { (HBV) }\end{array}$ & $\begin{array}{l}M \\
\mathrm{~F} \\
\mathrm{M} \\
\mathrm{F}\end{array}$ & $\begin{array}{r}1 \\
12 \\
9 \\
5\end{array}$ & $\begin{array}{l}\text { Active } \\
\text { Active } \\
\text { Active } \\
\text { Active }\end{array}$ & $\begin{array}{l}\text { None } \\
\text { None } \\
\text { None }\end{array}$ & $\begin{array}{l}\text { Present } \\
\text { Present } \\
\text { Present } \\
\text { Absent }\end{array}$ & $\begin{array}{l}2 \\
3 \\
3 \\
3\end{array}$ & $\begin{array}{l}2 \\
3 \\
3 \\
1\end{array}$ & $\begin{array}{r}147 \\
142 \\
490 \\
24\end{array}$ & $\begin{array}{l}\text { ND } \\
12 \cdot 5 \\
\text { ND } \\
16 \cdot 7\end{array}$ & $\begin{array}{l}\text { ND } \\
\text { Negative } \\
\text { ND } \\
\text { Negative }\end{array}$ & $\begin{array}{l}\text { ND } \\
\text { Negative } \\
\text { ND } \\
\text { Negative }\end{array}$ & $\begin{array}{l}\text { ND } \\
\text { Negative } \\
\text { ND } \\
\text { Negative }\end{array}$ \\
\hline
\end{tabular}

AlATD $=\mu_{1}$-antitrypsin deficiency; WD $=$ Wilson's disease; and $\mathrm{HBV}=$ hepatitis $\mathrm{B}$ virus.

AIATD $=\alpha_{1}$-antitrypsin deficiency; $\mathrm{WD}=$ Wilson's disease; and $\mathrm{HBV}=$ hepatitis

+ Liver biopsy samples were
$\ddagger$ Normal values $<45$ IU/l.

§Normal values for children aged between 2 and 5 years $>5-<17 \mathrm{~g} / \mathrm{l} ; 5$ and 16 years $>7-<18 \mathrm{~g} / \mathrm{l}$.

iTitres $\geqslant 1: 40$. ANA=antinuclear antibody; ASMA =smooth muscle antibody; LKMI =liver kidney microsomal antibody type 1 . ND $=$ not determined. 
$30 \mathrm{mg} / \mathrm{kg} /$ day in 10 patients), though in one patient treatment had been discontinued for some time by his parents. The three patients tested at diagnosis had active disease with piecemeal necrosis in the liver biopsy sample. The patient who had interrupted treatment and five of the treated patients also had signs of active disease with increased levels of aspartate transaminase, IgG, and non-organ specific autoantibodies, and one had piecemeal necrosis. The three remaining patients, all receiving treatment, had no clinical, immunological, nor histological evidence of active disease. Cirrhosis was present in five patients.

Four children had other forms of chronic aggressive hepatitis (table 3): two had $\alpha_{1}$ antitrypsin deficiency, one had Wilson's disease, and one had hepatitis B surface antigen (HBsAg)/ hepatitis $\mathrm{B}$ e antigen (HBeAg) positive chronic active hepatitis. None of these patients was receiving immunosuppressive or antiviral treatment. All had signs of active disease and cirrhosis was present in three patients. These children were selected because their liver biopsy samples showed degrees of portal tract infiltration and piecemeal necrosis similar to those observed in chronic active hepatitis and primary sclerosing cholangitis.

\section{BIOPSY SAMPLES}

Liver tissue was obtained for diagnostic or management purposes using a $1.4 \mathrm{~mm}$ diameter Menghini needle. Informed consent for the liver biopsy was given by the parents of all children. Three to five millimetres of each biopsy sample were embedded in OCT medium (BDH, Poole, UK) and immediately stored in liquid nitrogen before immunohistochemical analysis; most of the specimen was fixed in formalin and processed for routine diagnostic histopathological examination. Liver biopsy samples were assessed for portal tract infiltration and piecemeal necrosis using a semiquantitative scale according to Scheuer $^{23}$ (none $=1$, mild $=2$, moderate $=3$, severe $=4$ ).

\section{IMMUNOLOGICAL REAGENTS}

Most of the monoclonal antibodies (table 4) used in this study were purified by protein $A$ or ion exchange chromatography from the super-

Table 4 Monoclonal antibodies used in this study

\begin{tabular}{llll}
\hline $\begin{array}{l}\text { Monoclonal } \\
\text { antibody }\end{array}$ & Antigen & PBMC subset & Dilution \\
\hline OKT3 & CD3 & Total T lymphocytes & $1 / 10$ \\
WT31 & TCR1 & w// T lymphocytes & $1 / 10$ \\
OKT4 & CD4 & h/i T lymphocytes & $1 / 10$ \\
OKT8 & CD8 & s/c T lymphocytes & $1 / 10$ \\
THB5 & CD21 & B lymphocytes & $1 / 5$ \\
OKM1 & CD11b & Monocytes/macrophages & $1 / 5$ \\
L.243 & HLA-DR & Activated T and B lymphocytes & $1 / 160$ \\
Anti-Tac & Monocytes/macrophages & $1 / 10$ \\
B73.1 & CD25 (IL-2R) & Activated T lymphocytes & $1 / 10$ \\
OKT9 & CD71 (TFR) & K/NK lymphocytes & $1 / 10$ \\
4F2 & Activated lymphocytes & $1 / 10$ \\
W6/32 & HLA-A,B,C & Activated lymphocytes & $1 / 160$ \\
BE3F9 & Bovine insulin & All PBMC & $1 / 2$ \\
\hline
\end{tabular}

Abbreviations: $P B M C=$ peripheral blood mononuclear cells; $(.)=$, cluster of differentiation: $\mathrm{TCR}=\mathrm{T}$ cell receptor; IL-2R=interleukin 2 receptor; $\mathrm{TFR}=$ transferrin receptor; $\mathrm{h} / \mathrm{i}=\mathrm{helper}$; inducer; $s / c=$ suppressor/cytotoxic; $K=$ killer; and $\mathrm{NK}=$ natural killer. natant or the ascitic fluid of hybridoma (American Type Culture Collection, Rockville) cultures in vitro or in vivo respectively. WT31 was purchased from Becton Dickinson. The monoclonal antibody BE3F9 (American Type Culture Collection) directed to bovine insulin was used as control.

Peroxidase conjugated rabbit antimouse immunoglobulin antiserum (Dakopatts, High Wycombe) was used to label the monoclonal antibodies in a two step immunoperoxidase technique. Immunological reagents were used at saturating concentrations, as determined in preliminary titration experiments using normal lymphoid tissue.

\section{STAINING PROCEDURE}

The biopsy samples were cut in a cryostat (Bright, Huntingdon) and $5 \mu \mathrm{m}$ thick sections were obtained and placed on to slides which had previously been coated with a $0.01 \%$ solution of poly-L-lysine and allowed to dry.

Sections were allowed to air dry for four to six hours, fixed in a 1:1 mixture of acetone and chloroform for 10 minutes and washed in three changes of phosphate buffered saline $(\mathrm{pH} \mathrm{7 \cdot 4)}$ for five minutes each.

To block the endogenous peroxidase, sections were covered with a $1 \%$ solution of hydrogen peroxide in phosphate buffered saline for 20 minutes. After washing, to block non-specific binding, sections were incubated for 10 minutes with phosphate buffered saline containing $10 \%$ normal rabbit serum and then incubated for 30 minutes with a dilution in phosphate buffered saline of the respective monoclonal antibody. Sections were washed again and incubated with a 5\% dilution in phosphate buffered saline of peroxidase conjugated rabbit antimouse immunoglobulin, which contained $5 \%$ normal AB serum, to prevent possible cross reactions between the monoclonal antibodies and human immunoglobulin present on the tissue section. Sections were then washed, immersed for eight minutes in a solution of $0.6 \mathrm{mg} / \mathrm{ml}$ of diaminobenzidine tetrahydrochloride and $0.03 \%$ hydrogen peroxide in phosphate buffered saline, rinsed in tap water, counterstained with Mayer's haematoxylin, washed again extensively in tap water, and finally mounted with a 9:1 mixture of glycerol and phosphate buffered saline. ${ }^{24}$

\section{MICROSCOPIC ANALYSIS}

Stained and unstained mononuclear cells in one to three portal tracts were counted using light microscopy by an observer unaware of the clinical details. The percentage of positive cells was calculated and expressed semiquantitatively, with $0=$ no positive cells, $1=$ minimal $(<10 \%)$, $2=$ mild $(>10 \%,<25 \%), 3=$ moderate $(>25 \%$, $<50 \%), \quad 4=$ abundant $(>50 \%,<75 \%)$, and $5=$ very abundant $(>75 \%)$ amounts of positive cells.

\section{STATISTICAL ANALYSIS}

Positivety scores and the CD4: CD8 ratios were statistically analysed using Wilcoxon's rank sum test and Spearman's rank correlation method. 


\section{Results}

Stained liver sections were well preserved and tissue structures were easily recognisable. The amount of the mononuclear cell infiltrate in the portal tracts was more abundant in patients with active than inactive disease irrespective of treatment. No positive staining was observed using the control monoclonal antibodies, whereas positive cells labelled by the relevant monoclonal antibodies were identified by the reaction product deposited along their membranes. The amounts of mononuclear cell subsets in portal tracts are given in table 5. Although the numbers of cells varied proportionally with the magnitude of the cellular infiltrate, the tissue distribution of the cells belonging to a particular subset tended to be constant within a given disease.

Results obtained using the monoclonal antibody WT31 were similar to those obtained with OKT3, suggesting the existence of a homogeneous mononuclear cell subset simultaneously bearing $\mathrm{T}$ cell receptor 1 and CD3. T Lymphocytes (CD3 positive cells) were the most common infiltrating element in all disorders. When they were subtyped, helper/inducer $T$ cells (CD4 positive) were the most common in autoimmune chronic active hepatitis, were as numerous as suppressor/cytotoxic T cells (CD8 positive) in primary sclerosing cholangitis, and were in a minority in the other forms of chronic aggressive hepatitis, in which suppressor/ cytotoxic $\mathrm{T}$ cells were almost the only lymphocytes present. The CD4 to CD8 ratio was significantly higher in biopsy samples from patients with autoimmune chronic active hepatitis than in those from children with primary sclerosing cholangitis $(p<0.05)$ and in the latter it was higher compared with those from patients with other forms of chronic aggressive hepatitis $(p<0.01)$. Independent of diagnosis, helper/inducer $T$ cells tended to occupy the central areas of the portal tracts (fig 1 ) whereas suppressor/cytotoxic $\mathbf{T}$ cells formed the majority in areas of piecemeal necrosis and could often be observed at the front of the infiltrate invading the hepatic lobule (fig 2). In contrast with helper/inducer $T$ cells, which tended to remain confined within the portal tract, suppressor/cytotoxic $T$ cells could also be identified throughout the lobule, occupying perisinusoidal positions.

B lymphocytes (CD21 positive cells) were rarely or never found in the liver mononuclear cell infiltrate. In follicle-like lymphoid aggregates observed in the portal tracts from two patients with autoimmune chronic active hepatitis, three with primary sclerosing cholangitis, and one with $\alpha_{1}$-antitrypsin deficiency, however, $B$ cells represented the main constituents and also displayed the receptors for transferrin and interleukin 2 (fig 3).

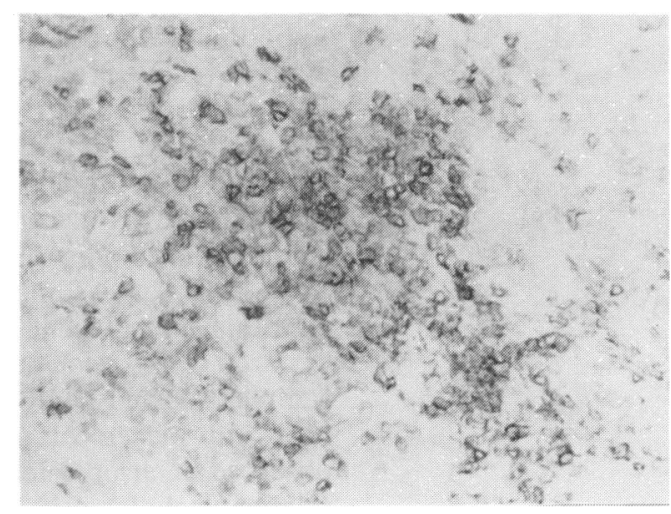

Figure 1 Liver section from a patient with autoimmune chronic active hepatitis stained for the CD8 molecule (suppressor/cytotoxic T lymphocytes). (Immunoperoxidase stain $\times 200$.

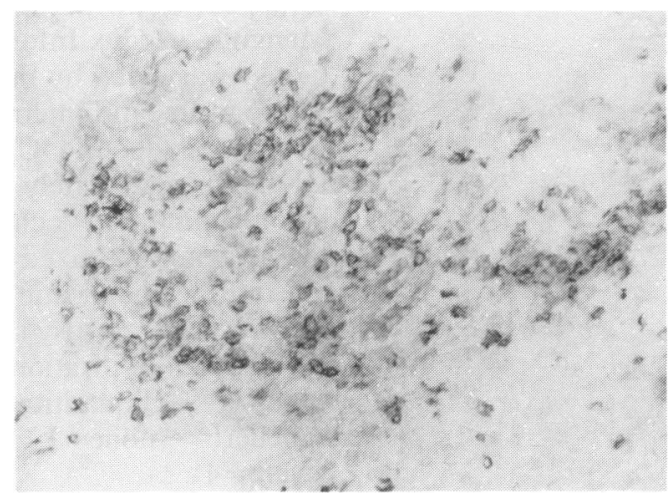

Figure 2 Liver section from a patient with primary sclerosing cholangitis stained for the CD8 molecule (suppressor/cytotoxic T lymphocytes). Positively stained suppressor/cytotoxic $T$ cells project inside the hepatic lobule. (Immunoperoxidase stain $\times 200$.)

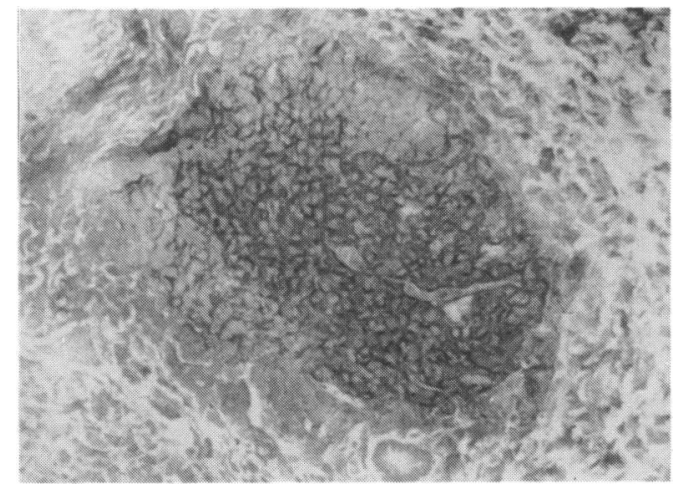

Figure 3 Liver section from a patient with autoimmune chronic active hepatitis stained for the CD21 molecule (B-lymphocytes). B Cells are positively stained in a follicle-like structure in a portal tract. (Immunoperoxidase stain $\times 200$.)

Table 5 Median (range) of positivity scores and CD4:CD8 ratios of portal tract mononuclear cell subsets in patients with autoimmune chronic active hepatitis, primary sclerosing cholangitis, or other forms of chronic active hepatitis

\begin{tabular}{|c|c|c|c|}
\hline & $\begin{array}{l}\text { Autoimmune } \\
\text { chronic active } \\
\text { hepatitis" }\end{array}$ & $\begin{array}{l}\text { Primary } \\
\text { sclerosing } \\
\text { cholangitis }\end{array}$ & $\begin{array}{l}\text { Other forms } \\
\text { of chromic } \\
\text { active hepatitis }\end{array}$ \\
\hline $\begin{array}{l}\text { Function markers: } \\
\text { CD3 } \\
\text { TCR1 } \\
\text { CD4 } \\
\text { CD8 } \\
\text { CD4:CD8 } \\
\text { CD21 } \\
\text { CD16 } \\
\text { CD11b }\end{array}$ & $\begin{array}{l}4 \cdot 5(4-5) \\
4 \cdot 5(4-5) \\
3 \cdot 5(3-4) \\
2 \cdot 5(1-3) \\
2 \cdot 1(1-4) \\
0(0-1) \\
2 \cdot 0(1-2) \\
1 \cdot 0(1-1)\end{array}$ & $\begin{array}{l}4 \cdot 0(4-5) \\
4 \cdot 0(4-5) \\
3 \cdot 0(2-4) \\
3 \cdot 0(2-4) \\
1 \cdot 0(0 \cdot 5-1 \cdot 5) \\
0 \\
1 \cdot 0(0-1) \\
3 \cdot 0(1-3)\end{array}$ & $\begin{array}{l}4 \cdot 0(4-5) \\
4 \cdot 0(4-5) \\
1 \cdot 0(1-1) \\
4 \cdot 0(4-5) \\
0 \cdot 1(0 \cdot 1-0 \cdot 2) \\
0(0-1) \\
1 \cdot 0(0-1) \\
2 \cdot 5(1-3)\end{array}$ \\
\hline $\begin{array}{l}\text { Activation markers: } \\
\text { HLA-DR } \\
\text { CD25 (IL2R) } \\
\text { CD71 (TFR) } \\
\text { 4F2Ag }\end{array}$ & $\begin{array}{l}5 \cdot 0(4-5) \\
3 \cdot 0(1-5) \\
4 \cdot 0(2-5) \\
3 \cdot 0(2-5)\end{array}$ & $\begin{array}{l}4 \cdot 0(4-5) \\
3 \cdot 0(1-4) \\
3 \cdot 0(2-5) \\
3 \cdot 0(2-5)\end{array}$ & $\begin{array}{l}4 \cdot 0(2-4) \\
1 \cdot 0(0-2) \\
3 \cdot 0(3-4) \\
2 \cdot 0(1-3)\end{array}$ \\
\hline
\end{tabular}

Number of positive cells: $0=$ none; $1=<10 \% ; 2=>10 \%,<25 \% ; 3=>25 \%,<50 \% ; 4=>50 \%$ $<75 \% ; 5=>75 \%$. 
Killer/natural killer cells (CD16 positive) were the more numerous subset in patients with autoimmune chronic active hepatitis after $T$ lymphocytes, being present in all patients and forming up to a quarter of the mononuclear cell infiltrate. Occasionally they could also be seen scattered within the liver lobule, with a pattern of distribution similar to that described for suppressor/cytotoxic $T$ cells. In patients with primary sclerosing cholangitis and the other forms of chronic aggressive hepatitis they were rare or absent.

Monocytic cells (CD11b positive) were found in all patients, but they were relatively more numerous in patients with primary sclerosing cholangitis, $\alpha_{1}$-antitrypsin deficiency, Wilson's disease, and hepatitis B virus related chronic active hepatitis than in autoimmune chronic active hepatitis, in which they were a rare, though consistent, finding.

Mononuclear cells expressing markers of activation were detected in all patients. HLADR was the activation marker most often encountered, and in all patients with autoimmune chronic active hepatitis and primary sclerosing cholangitis it was expressed on most of the mononuclear cell infiltrate. IL-2R (CD25) was also found on the mononuclear cell infiltrate in all patients with autoimmune chronic active hepatitis and primary sclerosing cholangitis (fig 4), the number of positive cells ranging from minimal to abundant, although it was a rare finding in the other forms of chronic aggressive hepatitis. Transferrin receptors (CD71) and the antigens targeted by 4F2 (4F2Ag) were found in all patients with chronic aggressive hepatitis investigated without variations among different forms of the disease.

The numbers of cells displaying activation markers varied widely among patients, especially those with autoimmune chronic active hepatitis and primary sclerosing cholangitis. Untreated patients with either autoimmune chronic active hepatitis or primary sclerosing cholangitis tended to have scores of cells positive for activation markers higher than those receiving treatment; this difference was statistically significant for IL-2R $(\mathrm{p}<0.04$ and $\mathrm{p}<0.02$ respectively) (fig 5). Scores of positive cells tended to parallel the activity of the disease and the extent of portal tract infiltrate and piecemeal necrosis,

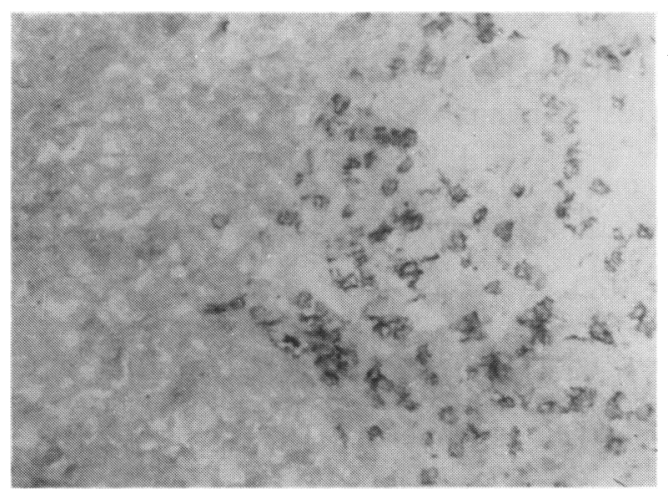

Figure 4 Liver section from a patient with primary sclerosing cholangitis stained for the CD25 molecule. Positive cells are seen in the portal tract. (Immunoperoxidase stain $\times 200$.)

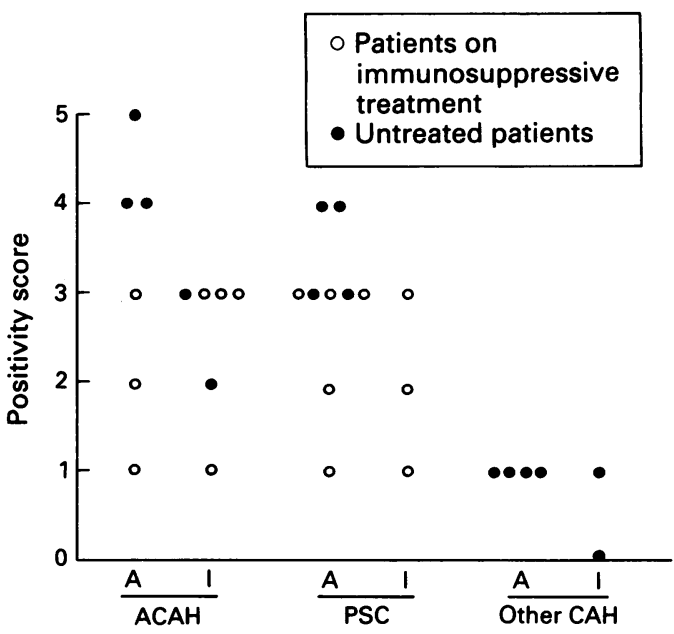

Figure 5 Positivity scores for the CD25 molecule in the patient groups divided according to active and inactive disease. $A C A H=$ autoimmune chronic active hepatitis; $P S C=$ primary sclerosing cholangitis; Other $C A H=$ other forms of chronic aggressive hepatitis; $A=$ active; $I=$ inactive.

but they were not affected by the presence or absence of cirrhosis.

\section{Discussion}

This study shows that $\mathrm{T}$ lympocytes predominate in the portal tract infiltrate of children with various forms of chronic aggressive hepatitis, but the distribution of their markers of function and activation differs according to diagnosis.

Two major patterns of mononuclear cell infiltrate were observed: one typical of autoimmune chronic active hepatitis (characterised by helper/inducer $T$ cells outnumbering suppressor/cytotoxic $\mathrm{T}$ cells, a small amount of killer/natural killer cells and a high proportion of activated cells) and one typical of primary sclerosing cholangitis (characterised by similar amounts of helper/inducer and suppressor/ cytotoxic $T$ cells, mild to moderate amounts of monocytes/macrophages, with most cells being activated). In the chronic aggressive hepatitis due to $\alpha_{1}$-antitrypsin deficiency, Wilson's disease, or chronic hepatitis B infection we observed abundant suppressor/cytotoxic $\mathrm{T}$ cells prevailing over helper/inducer $\mathrm{T}$ cells and rarer cells expressing IL-2R.

Independent of the cause of chronic aggressive hepatitis or disease activity, akin to observations in adults, ${ }^{479101213} \mathrm{~T}$ lymphocytes were the major component of the portal tract mononuclear cell infiltrate in all the children studied. In addition, we have found that the infiltrating $T$ cells expressed mainly $T$ cell receptor 1 . Further studies using monoclonal antibodies directed against the $\gamma \sigma \mathrm{T}$ cell receptor ${ }^{25} 26$ will elucidate the presence of $T$ cell receptor 2 positive T lymphocytes.

T cells expressing the suppressor/cytotoxic phenotype were similarly represented in all patients and were concentrated at the periphery of the portal tract and in areas of piecemeal necrosis. This distribution suggests that these cells are cytotoxic lymphocytes and mediate the liver cell damage typical of chronic aggressive 
hepatitis, irrespective of its aetiology. In contrast with suppressor/cytotoxic $\mathrm{T}$ cells, the proportion of helper/inducer $T$ cells was markedly different in the various groups of patients with chronic aggressive hepatitis studied. Similar to observations in adults; ${ }^{561213}$ numerous CD4 positive T lymphocytes were found in the biopsy samples from children with autoimmune chronic active hepatitis and primary sclerosing cholangitis, being especially abundant in the former. Independent of diagnosis, these regulatory lymphocytes were particularly prominent in the centre of the portal tracts, suggesting that they may orchestrate local immune reactions, through antigen recognition, activation of cytotoxic $T$ cells, B lymphocytes and macrophages, and cytokine production. ${ }^{27}$ It is also possible that some of them may modulate tissue damaging immune reactions, as $\mathrm{CD} 4$ positive $\mathrm{T}$ lymphocytes can act as suppressor cells. ${ }^{28}$ In contrast with the results in autoimmune chronic active hepatitis and primary sclerosing cholangitis, CD4 positive cells were present in small numbers in children with other forms of chronic aggressive hepatitis.

The CD4:CD8 ratio was significantly higher in patients with autoimmune chronic active hepatitis than in those with primary sclerosing cholangitis and in the latter when compared with the other forms of chronic aggressive hepatitis. This finding is similar to those obtained in a number of studies of adults ${ }^{51213}$ and suggests that the CD4:CD8 ratio in the portal tract mononuclear cell infiltrate in liver biopsy samples with features of chronic aggressive hepatitis could be of diagnostic value. The CD4:CD8 ratio of greater than unity observed in the liver in autoimmune chronic active hepatitis reflects the CD4:CD8 ratio of the activated $T$ lymphocytes in the peripheral blood of children with this disease. ${ }^{20}$ Similarly, the CD4: CD8 ratio of the infiltrate in patients with primary sclerosing cholangitis parallels the ratio observed within activated $\mathrm{T}$ cells in the peripheral blood. ${ }^{21}$

B lymphocytes were seen at low levels or not at all, whatever the cause of chronic aggressive hepatitis. This observation is surprising because of the high immunoglobulin production and the high titres of liver and non-liver specific autoantibodies which characterise diseases such as autoimmune chronic active hepatitis and primary sclerosing cholangitis. In four biopsy samples, however, including two patients with autoimmune chronic active hepatitis and one with primary sclerosing cholangitis, B lymphocytes were observed in follicle-like structures present within some portal tracts, confirming a similar finding reported previously. ${ }^{29}$ These structures appear to be unevenly distributed and may have been absent in the other biopsy samples, owing to the small amount of tissue studied. Such an organisation of rudimentary lymphoid tissue within the liver is likely to be a consequence of intense cytokine stimulation in the portal tracts, and this view is supported by evidence that the $B$ cells observed in these structures expressed activation markers.

Killer/natural killer cells, though not numerous, were the most common subset after
T lymphocytes in autoimmune chronic active hepatitis, whereas they were rare or absent in the other disorders. This observation reinforces the idea that non-major histocompatibility complex restricted cytotoxicity, including antibody dependent cell mediated cytotoxicity, is likely to be of importance in the development of liver injury in autoimmune chronic active hepatitis. ${ }^{30} 31$

Monocytic cells were always identified, but though they were rare in patients with autoimmune chronic active hepatitis, they were found in small or moderate numbers in patients with primary sclerosing cholangitis and the other forms of chronic aggressive hepatitis, in which they could be involved in the generation of tissue damage, possibly by effecting antibody dependent cell mediated cytotoxicity. ${ }^{32}$

In autoimmune chronic active hepatitis and primary sclerosing cholangitis most mononuclear cells infiltrating the portal tracts displayed activation markers, indicating that they actively affect the immune response. The finding that reduced activation marker expression occurred with treatment and in inactive disease also supports this conclusion. This observation is consistent with the results obtained by measuring IL-2R positive $T$ lymphocytes and soluble IL-2R in the peripheral blood of treated and untreated children with autoimmune chronic active hepatitis. ${ }^{20} 33$ Interestingly, in patients with primary sclerosing cholangitis the proportion of peripheral blood $\mathrm{T}$ lymphocytes expressing IL-2R is markedly lower than in autoimmune chronic active hepatitis, irrespective of disease activity, ${ }^{20}$ though the proportion of these cells in the portal tract inflammatory infiltrate is as high as in autoimmune chronic active hepatitis. This finding may reflect a more generalised autoimmune reaction in autoimmune chronic active hepatitis, where some of the peripheral IL-2R positive T cells may be sensitised to tissues other than the liver.

In conclusion, this study shows the existence of different patterns of expression of markers of function and activation in the portal tract mononuclear cell infiltrate in patients with autoimmune chronic active hepatitis and primary sclerosing cholangitis, and corroborates our previous observations on peripheral blood mononuclear cells, ${ }^{21}$ suggesting that despite the clinical and histological similarities the mechanisms leading to autoimmune liver damage in these two diseases are different.

Dr Senaldi was a research fellow in the department of immunology of King's College School of Medicine and Dentistry and was supported by the Royal Society, UK. Dr Mieli-Vergani is supported by the Children's Liver Disease Foundation, formerly the Micheal McGough Foundation against Liver Disease in Children, UK. B73.1 and anti-Tac were a gift of Dr B Perussia and Dr T A Waldmann respectively.

1 De Groote J, Desmet VJ, Gedigk P, et al. A classification of chronic hepatitis. Lancet 1968;ii:626-9.

2 Scheuer PJ. Chronic hepatitis: a problem for the pathologist.

Histopathology 1977;1:5-19.
3 Alexander G, Williams R. Characterisation of the mononuclear cell infiltrate in piecemeal necrosis. Lab Invest 1984;50:247-9.

4 Eggink HF, Houthoff HJ, Huitem S, Gips CH, Poppema S. Cellular and humoral immune reactions in chronic active liver diseases. I. Lymphocyte subsets in liver biopsies of patients with untreated idiopathic autoimmune hepatitis, chronic active hepatitis B and primary biliary cirrhosis. Clin Exp Immunol 1982;50:17-24. 
5 Colucci G, Colombo M, Del Ninno E, Paronetto F. In situ characterization by monoclonal antibodies of the mono-
nuclear cell infiltrate in chronic active hepatitis. Gastronuclear cell infiltrate in chrology $1983 ; 85: 1138-45$.

6 Si L, Whiteside TL, Van Thiel DH, Rabin BS. Lymphocyte subpopulations at the site of piecemeal necrosis in end stage chronic liver diseases and rejecting liver allografts in cyclosporine-treated patients. Lab Invest 1984;50:341-7.

7 Montano L, Miescher GC, Goodall AH, Wiedmann KH Janossy G, Thomas HC. Hepatitis B virus and HLA antigen display in the liver during chronic hepatitis $B$ virus infection. Hepatology 1982;2:557-61.

8 Pape GR, Rieber EP, Eisenburg J, et al. Involvement of the cytotoxic suppressor T-cell subset in liver tissue injury of patients with acute and chronic liver diseases. Gastroentero$\log y$ 1983;85:657-62.

9 Eggink HF, Houthoff HJ, Huitema S, Wolters G, Poppema $\mathrm{S}$, Gips $\mathrm{CH}$. Cellular and humoral immune reactions in chronic active liver diseases. II. Lymphocyte subsets and viral antigens in liver biopsies of patients with acute and viral antigens in liver biopsies of patients with acute
chronic hepatitis B. Clin Exp Immunol 1984;56:121-8.

10 Dienes HP, Hutteroth T, Hess G, Meuer SC. Immunoelectron microscopic observations on the inflammatory infiltrates microscopic observations on the inflammatory infiltrates and HLA antigens in he

11 Si L, Whiteside TL, Schade RR, Starzl TE, Van Thiel D. T-lymphocyte subsets in liver tissues of patients with primary biliary cirrhosis (PBC), patients with primary scherosing cholangitis (PSC), and normal controls. J Clin Immunol 1984;4:262-72.

12 Snook JA, Chapman RW, Sachdev GK, et al. Peripheral blood and portal tract lymphocyte populations in primary sclerosing cholangitis. F Hepatol 1989;9:36-41.

13 Whiteside TL, Lasky S, Si L, Van Thiel DH. Immunologic analysis of mononuclear cells in liver tissues and blood of patients with primary sclerosing cholangitis. Hepatology patients with

14 Si L, Whiteside TL, Schade RR, Van Thiel D. Lymphocyte subsets studied with monoclonal antibodies in liver tissues of patients with alcoholic liver disease. Alcoholism Clin Exp Res 1983;7:431-5.

15 El-Shabrawi M, Wilkinson M, Portmann B, et al. Primary sclerosing cholangitis in childhood. Gastroenterology 1987 92:1226-35.

16 Bortolotti F, Calzia R, Vegnente A, et al. Chronic hepatitis in childhood: the spectrum of the disease. Gut 1988;29: 659-64.

17 Sternlieb I, Perspective on Wilson's disease. Hepatology 1990; 12:1234-9.

18 Sharp HL, Bridges RA, Krivit W, Freier EF. Cirrhosis associated with $\alpha_{1}$-antitrypsin deficiency: a previously unrecognised inherited disorder. F Lab Clin Med 1969;73: 934-9.
19 Fukui K, Kakumu S, Murakami H, Kuriki J, Yoshioka K Sakamoto $\mathbf{N}$. Increased peripheral blood Ia positive $\mathrm{T}$ cells and their effect on autologous mixed lymphocyte reaction in chronic active liver disease. Clin Exp Immunol 1984;58: in ch 6 .

20 Lobo-Yeo A, Alviggi L, Mieli-Vergani G, Portmann B Mowat AP, Vergani D. Preferential activation of helper/ inducer $T$ lymphocytes in autoimmune chronic active hepatitis. Clin Exp Immunol 1987;67:95-103.

21 Mieli-Vergani G, Lobo-Yeo A, McFarlane BM, McFarlane IG, Mowat AP, Vergani D. Different immune mechanisms leading to autoimmunity in primary sclerosing cholangitis and autoimmune chronic active hepatitis of childhood. Hepatology 1989;9:198-203.

22 Sherlock S. Chronic autoimmune 'lupoid' hepatitis. Diseases of the liver and biliary system. 8th Ed. Oxford: Blackwell, 1989:348-56.

23 Scheuer PJ. Classification of chronic viral hepatitis: a need for reassessment. F Hepatol 1991;13:372-4.

24 Graham RC, Karnovski MJ. The early stages of absorption of injected horseradish peroxidase in the proximal tubules of injected horseradish peroxidase in the proximal tubules of mouse kidney. Ultrastructural cytochemistry

25 Groh V, Porcelli S, Fabbi M, et al. Human lymphocytes bearing $T$ cell receptor gamma/delta are phenotypically diverse and evenly distributed throughout the lymphoid system. F Exp Med 1989;169:1277-87.

26 Seki H, Nanno M, Chen PF, et al. Molecular heterogeneity of $\gamma \delta$ T-cell antigen receptors expressed by CD CD T-cell clones from normal donors: both disulphide- and nondisulphide-linked receptors are oTCS1 ${ }^{\prime}$. Proc Natl Acad Sci USA 1989;86:2326-30.

27 Janeway CA Jr, Carding S, Jones B, et al. CD4 ${ }^{+}$T-cells: specificity and function. Immunol Rev 1988;101:39-80.

28 Lanzavecchia A. Is suppression a function of class IIrestricted cytotoxic T cells? Immunol Today 1989;10:157-8.

29 Ballardini G, Fallani M, Bianchi FB. Autoimmune chronic liver disease: local or systemic immunological activation? liver disease: local or system

30 Mieli-Vergani G, Vergani D, Jenkins PJ, et al. Lymphocyte cytotoxicity to autologous hepatocytes in $\mathrm{HBsAg}$-negativ

31 Kaneda K, Kurioka N, Seki S, Wake K, Yamamoto S. Pi cell-hepatocyte contact in autoimmune hepatitis. Hepatology 1984;4:955-8.

32 Bernau D, Rogier E, Feldmann G. A quantitative ultrastructural analysis of the leukocytes in contact with hepatocytes in chronic active hepatitis with a cytochemica detection of mononuclear phagocytes. Am $\mathcal{F}$ Pathol 1982; 109:310-4.

33 Lobo-Yeo A, Mowat AP, Mieli-Vergani G, Vergani D. Soluble interleukin-2 receptors in autoimmune chronic active hepatitis. Gut 1990;31:690-3. 